\title{
THE 2010 CHILEAN AND THE 2011 TOHOKU TSUNAMI WAVES IMPACT TO RIVERS IN THE TOHOKU REGION, JAPAN
}

\author{
Hitoshi Tanaka ${ }^{1}$ and Nguyen Xuan Tinh ${ }^{2}$
}

\begin{abstract}
As a result when tsunami invades into river, it may not only a threat of damages to the banks but also cause the environmental problem such as inundation. Therefore, study of tsunami impacts to rivers becomes more important. The main objectives of this study are to investigate the tsunami wave propagation at different river morphologies based on real time measurements during the 2010 Chilean Tsunami and 2011 Tohoku Tsunami events. The aim is to learn empirically from the last extreme events tsunamis in order to suggest a better solution in terms of river and coastal management in the future. The analyzed results have been shown that the tsunami wave can be affected up to several tens kilometer upstream of a large river and the measured tsunami travel time inside the river is almost similar to the tsunami travel time calculated by using the long wave theory.
\end{abstract}

Keywords: 2010 Chilean Tsunami; 2011 Tohoku Tsunami; river mouth; river upstream; tsunami wave impact

\section{INTRODUCTION}

There were two serious Chile and Great Tohoku Earthquakes, rating magnitude of 8.8 and 9.0, took place on February 27, 2010 and March 11, 2011 respectively caused great tsunami waves and devastating coastal areas of Chile and Japan. This study will mainly focus on the effects of these two tsunami events to the total 25 rivers in Tohoku Region of Japan. In order to achieve the objectives, an attempt is made to collect as many required data sets as possible for all studied rivers.

There have been quite a lots of studies on tsunami impacts to the coastal areas but very limited number studies on its impacts to the rivers such as Abe (1986), Tsuji et al. (1991), Sato et al. (1995), Tanaka et al. (2008) and Yasuda (2010). Among them Abe (1986) has found that the tsunami wave can propagate up to $15 \mathrm{~km}$ river upstream. Resonance occurred in river in about 80 minutes and causing a standing wave.

Tsunami waves propagate to river area, it may not only a threat of damages to the embankments but also cause the environmental problem such as inundation and saline water intrude to the rice field areas. Therefore, the study of tsunami impacts to river upstream becomes more important. The main objective of this study is to investigate the tsunami wave propagation at different river morphologies. The analyzed results have been shown that the tsunami wave can be affected up to about $50 \mathrm{~km}$ upstream of a large river and the measured tsunami travel time inside the river is almost similar to the tsunami travel time calculated by using the long wave theory. These empirical lessons might help the local river or coastal authority and management to find the best solution to minimum the impacts of tsunami as well as to warn the people living in river upstream areas pay more attention to the tsunami influences.

\section{DATA COLLECTION AND ANALYSIS}

In order to archive the objectives, an attempt is made to collect as many required data sets as possible for all studied rivers. The data are included: Water level measurement along the upstream of river, nearby estimated tidal level, river mouth morphology and aerial photographs. Based on these data, a quantitative analysis of morphology changes can be attained. These complied data sets enable us to examine the coastal morphological responses such as sediment erosion or deposition due to a large tsunami and also to investigate the coastal and river morphology recovering processes after that.

\section{Study area}

Figure 1 shows the location of studied rivers in the Tohoku District area in Japan. This area consists of 6 Prefectures, however, there only 4 Prefectures, named as Aomori, Iwate, Miyagi and Fukushima, which face the Pacific Ocean were greatly impacted by the 2010 Chilean Tsunami and 2011 Tohoku Tsunami, will be focused on. An attempt is made to collect as many full data sets as possible from the local Prefectural Governments. In total, the data from 25 rivers were compiled and analyzed. Nevertheless, because of each river entrance has their own morphology so the influence of tsunami needs to be analyzed individually and compared among them. Because of the extreme

\footnotetext{
${ }^{1}$ Professor, Department of Civil Engineering, Tohoku University, 6-6-06 Aoba, Sendai 980-8579, Japan

${ }^{2}$ Postdoc Fellow, Department of Civil Engineering, Tohoku University, 6-6-06 Aoba, Sendai 980-8579, Japan 
earthquake and tsunami in March 2011, a lot of stations close river mouth were either completely destroyed or lost electricity, so there are a few survival station data collected during the 2011 event.
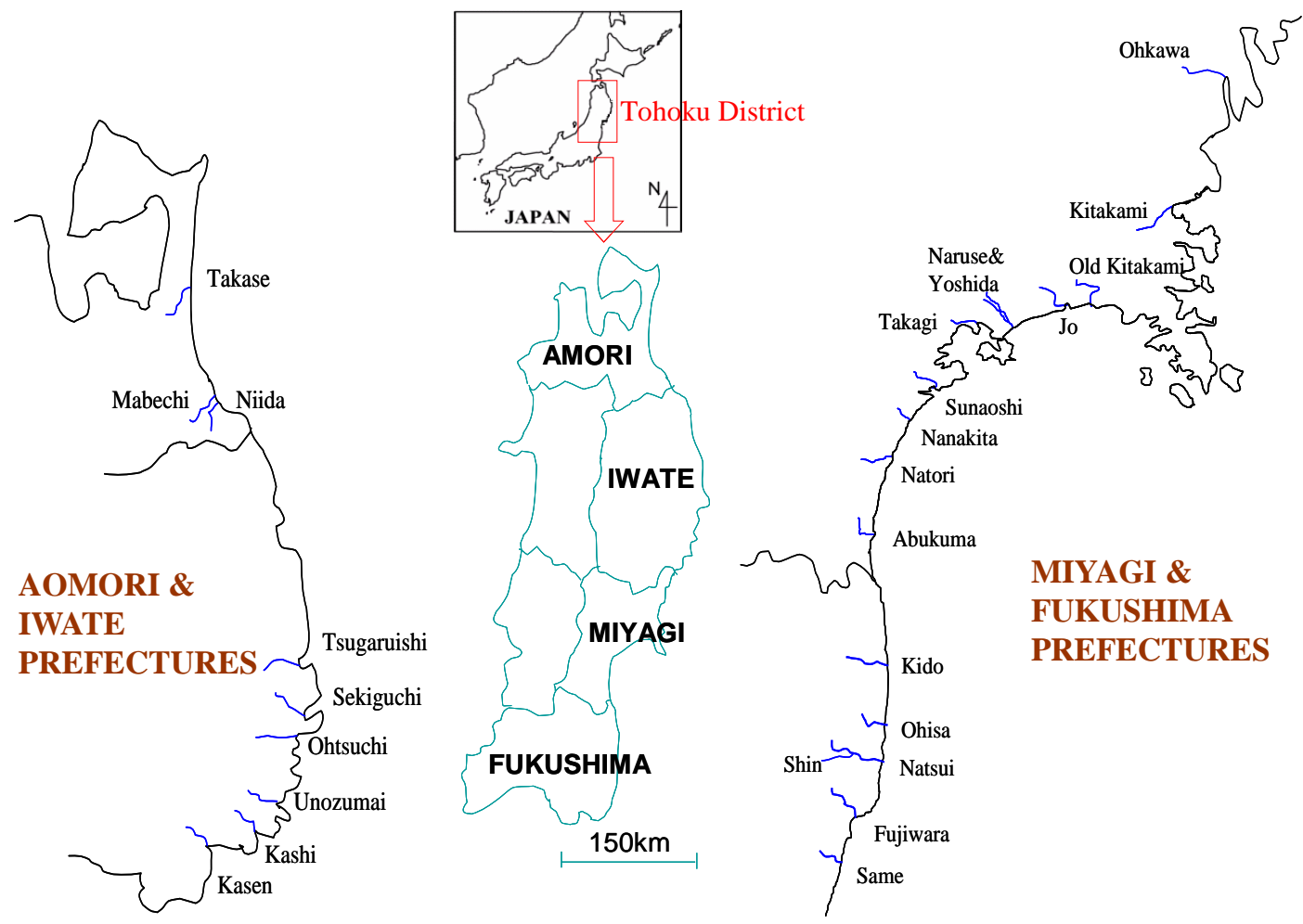

Figure 1. Location of study areas

\section{Water level measurement}

In Japan, water level was often measured at 1 hour of time interval in a normal condition, however, due to some short-term extreme events such as typhoons or tsunami the measurement method can be switched to smaller time interval in order to catch more details the wave peaks of event. In this study, 10 minutes time interval water level measurement data were collected for all rivers. As an example, Figs 2(a), (b) show the measurement water level data at the Naruse River during the 2010 Chilean and the 2011 Tohoku Tsunamis events, respectively. These water level data are then compared to the closest predicted tidal station which is Ayukawa tidal station. The difference between water level in river and estimated tidal level can be used to detect the tsunami fluctuations in the river as shown in Fig. 2.

There in total 25 rivers water data were collected during the 2010 event. However, because of the extreme tsunami wave height in the 2011 event, as it reached to the coast, destroyed almost of the downstream water stations. Therefore, there are only few stations survive and to obtain the data. The summary of data availability is shown in the Table 1 . 

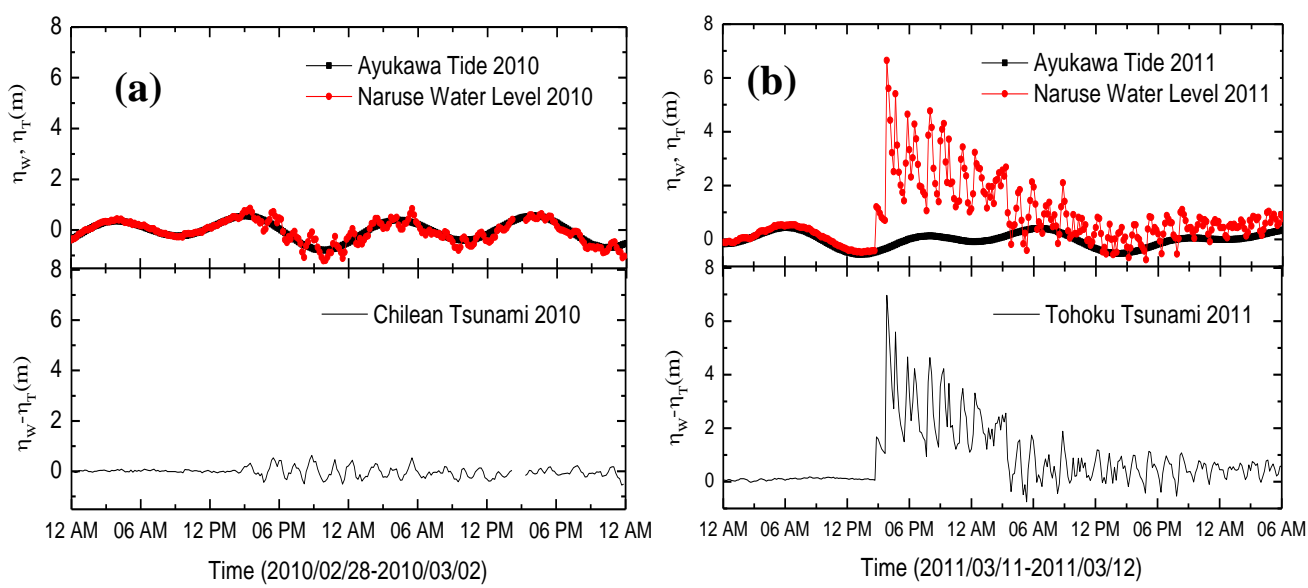

Figure 2. Measurement water level variation during the Chilean Tsunami 2010 and the Tohoku Tsunami 2011

\section{River mouth morphology}

Japanese Rivers were classified into two different categories Class-A and Class-B according their dimensions and its importance. The Class-A rivers have relatively larger in terms of catchment and river morphology as compared to the Class-B rivers. The former are governed by the national government, while the latter by prefectural government.

The characteristics of each individual river are different in each prefecture. For example, there are many rivers in Iwate Prefecture flow into the steep rocky coast. Some rivers poured into the port or a hard structure located at entrance such as the Mabechi River in Aomori Prefecture; Old Kitakami, Naruse, Sunaoshi, Natori Rivers in Miyagi Prefecture and Fujiwara River in Fukushima Prefectrue. The others rivers have sand spits at the entrance like the Takase, Kitakami, Nanakita and Abukuma Rivers. Based on the characteristics of rivers in these prefectures, two types of river mouth morphologies are sub-divided to examine the tsunami runup influences to river upstream since tsunami energy dissipation before its invasion into river is highly dependent on the river mouth morphology. Hereafter, the analysis is based on these classifications.

Type 1: with non-constricted jetties or located inside a port. (Full-width wave energy intrusion) Type 2: with sand spit or with constricted jetties (Divergent wave energy intrusion)
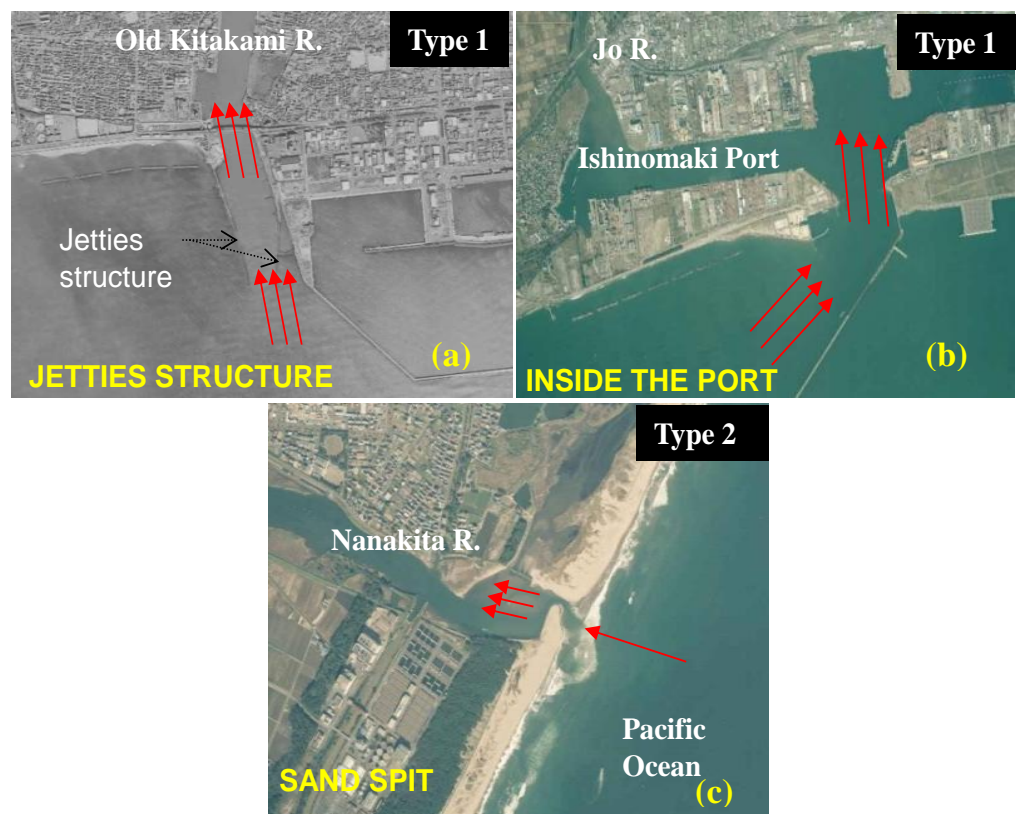

Figure 3. Classification of Type 1 River (Full-width energy intrusion) and Type 2 River (Divergent wave energy intrusion) 
Figure 3 shows typical river mouth morphologies for the Type 1 and Type 2 Rivers. Table 1 illustrates the summary of all river data collections and river class types as well as its river mouth morphology classification.

Table 1: Summary of River mouth morphology and tsunami data availability

\begin{tabular}{|c|c|c|c|c|c|c|c|}
\hline Prefecture & River name & Class & $\begin{array}{c}\text { First station } \\
\text { from river } \\
\text { mouth }(m)\end{array}$ & $\begin{array}{l}\text { River mouth } \\
\text { morphology }\end{array}$ & Type & $\begin{array}{c}2010 \\
\text { Chilean } \\
\text { Tsunami }\end{array}$ & $\begin{array}{c}2011 \\
\text { Tohoku } \\
\text { Tsunami }\end{array}$ \\
\hline \multirow{12}{*}{ Miyagi } & Kitakami & $A$ & 0.01 & Sand spit & 2 & 0 & 0 \\
\hline & Old Kitakami & A & 1.24 & Jetties structure & 1 & 0 & 0 \\
\hline & Naruse & $A$ & 0.50 & Jetties structure & 1 & 0 & 0 \\
\hline & Yoshida & $A$ & 0.50 & Jetties structure & 1 & 0 & 0 \\
\hline & Natori & A & 1.77 & Jetties structure & 1 & 0 & 0 \\
\hline & Abukuma & $A$ & 0.78 & Sand spit & 2 & 0 & 0 \\
\hline & Takagi** & B & 0.98 & Inside the Port & 1 & 0 & $x$ \\
\hline & Sunaoshi** & $B$ & 3.01 & Inside the Port & 1 & 0 & 0 \\
\hline & Nanakita & $B$ & 0.59 & Sand spit & 2 & 0 & 0 \\
\hline & Ohkawa & $B$ & 2.80 & Inside a bay & 1 & 0 & $x$ \\
\hline & Isatomae & B & 0.01 & Inside a bay & 1 & 0 & $x$ \\
\hline & Jo & $B$ & 3.50 & Inside the Port & 1 & 0 & $x$ \\
\hline \multirow{3}{*}{ Fukushima } & Natsui & B & 1.20 & Sand spit & 2 & 0 & $x$ \\
\hline & Fujiwara & $B$ & 3.70 & Inside the Port & 1 & 0 & $\times$ \\
\hline & Same & $B$ & 3.20 & Sand spit & 2 & 0 & 0 \\
\hline \multirow{3}{*}{ Aomori } & Mabechi & A & 1.20 & Inside the Port & 1 & 0 & $x$ \\
\hline & Takase & $A$ & 0.20 & Sand spit & 2 & 0 & $\times$ \\
\hline & Niida & $B$ & 5.00 & Inside the Port & 1 & 0 & $x$ \\
\hline \multirow{6}{*}{ Iwate } & Tsugaruishi & B & 1.50 & Inside a bay & 1 & 0 & $\times$ \\
\hline & Sekiguchi & $B$ & 3.10 & Sand spit & 1 & 0 & $\times$ \\
\hline & Kasen & $B$ & 3.00 & Jetties structure & 1 & 0 & $\times$ \\
\hline & Kashi & $B$ & 4.60 & Inside a bay & 1 & 0 & $\times$ \\
\hline & Unozumai & $B$ & 2.80 & Sand spit & 2 & 0 & $\times$ \\
\hline & Ohtsuchi & $B$ & 1.20 & Inside a bay & 1 & 0 & $x$ \\
\hline \multicolumn{8}{|l|}{ Notes: } \\
\hline $\begin{array}{l}* * \\
0 \\
x\end{array}$ & $\begin{array}{l}\text { Inalysis results } \\
\text { Data available } \\
\text { Vo data }\end{array}$ & based & one hour time & terval data set & & & \\
\hline
\end{tabular}

\section{RESULTS AND DISCUSSION}

\section{The 2010 Chilean Tsunami Waves Impacts}

\section{Tsunami responses to different river morphologies}

A comprehensive study about the impacts of the 2010 Chilean Tsunami waves to the Tohoku district have investigated by Tanaka at al. 2011. When the tsunami propagates into near shore areas, then its energy will be dissipated by the effects of topography and bottom friction. Especially when the tsunami waves come to the river area, the energy dissipation will depend largely on the river morphology. Each geographical features of river response to tsunami differently. According to the above river entrance morphology classification, Type 1 has non-constricted jetty at mouth or located inside a harbor as well as in a rocky bay thus there is no constriction in this type then most of wave energy at the entrance will be transferred to the river upstream and further reduced by bottom friction. 
Jo River, as a typical for the Type 1, is located inside the Ishinomaki Port in Miyagi Prefecture (Fig $3(\mathrm{~b})$ ). The width of river is gradually decreased to longitudinal direction. Fig. 4(a) also shows the comparison between measured water level at $3.5 \mathrm{~km}$ from the mouth and estimated tidal level at Ayukawa station. The water level was almost no distinguishing difference compared to tidal level before tsunami occurrence. However, the maximum displacement of $1.12 \mathrm{~m}$ was observed after several incoming tsunami waves. This indicates that wave energy tends to concentrate to the river. On the other hand, tsunami might easy intrude to in the Type 1 river mouth. This value is the largest tsunami height was observed during the 2010 Chilean Tsunami event. Roh et al. (2011) conducted a numerical hypotheses test the tsunami impacts to similar river mouth morphology type classification and shown the very similar behavior of tsunami responses in this Type 1 .

Type 2 River is a river mouth which has a constricted structure or sand spit at entrance. Thus, the wave energy is dissipated by wave breaking or shoaling effects in front of the mouth. As a result, the remained wave energy will penetrate and diverge into the river upstream. Fig. 3(c) and Fig. 4(b) show the aerial photograph and water variation during the tsunami event at Nanakita River. This river belongs to the Class B and Type 2. A small river discharge together with wave breaking often occurs at entrance even in the normal condition caused sediment deposited in front of river mouth and formed river-sand bar. The water depth and width at the entrance are remained shallow and narrow, respectively. Therefore, during the 2010 tsunami event most of the tsunami energy was dissipated either at the coastline or close river mouth areas. A very little tsunami height of $18 \mathrm{~cm}$ was observed only during high tide level in the Nanakita River. The impacts of tsunami to the Type 2 river mouth is much less than compared with its impact to the Type 1 River. Similar mechanism of tsunami impact is also found in the the Mabechi River and Takase River as shown in Fig. 5.
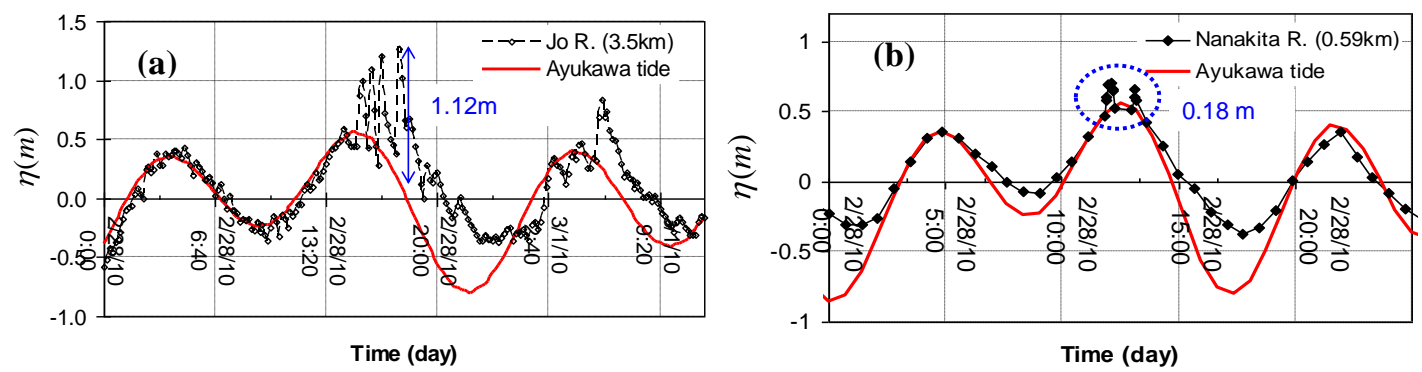

Figure 4. Tsunami responses to the Jo River (Type 1) and to the Nanakita River (Type 2)
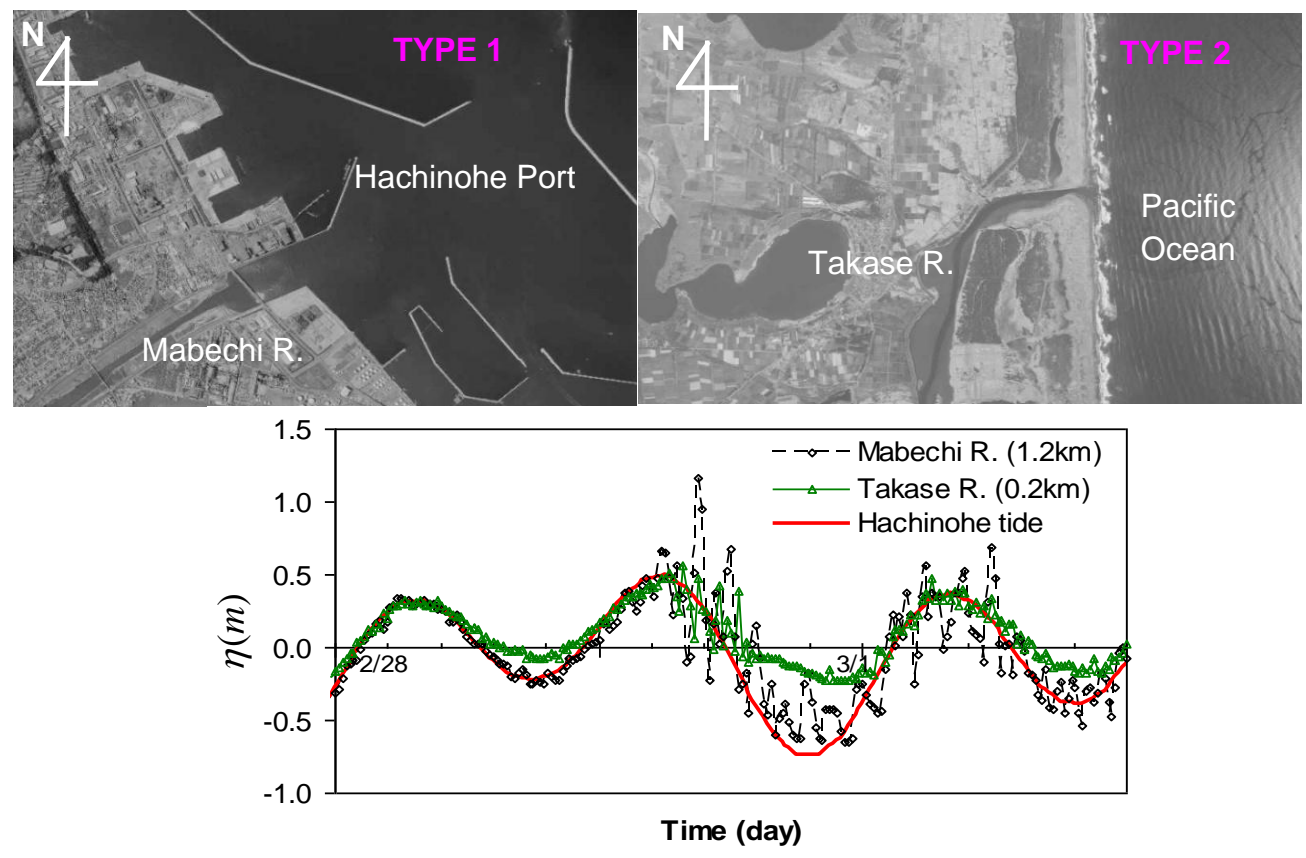

Figure 5. Tsunami responses in the Mabechi River (Type 1) and in the Takase River (Type 2) 
Tsunami wave variation along river

The first and second tsunami peaks from each observation point are chosen in order to analyse the variation of tsunami wave along river since from the third wave it might be affected by return waves. Figure 6 illustrates the river topography and the analysis results of the first and second tsunami peaks along the Old Kitakami River. This river flows into the Ishinomaki Port and has two long parallel jetties at the entrance; it therefore represents for the Type 1 River. The river water depth and width at entrance are remained as deep and wide for navigation transportation purposes. Because of this, tsunami wave can easy propagate far upstream area. The uppermost point of observed tsunami in the Old Kitakami River is about $33 \mathrm{~km}$ from the mouth (see Fig. 6). Tsunami can also propagate up to small Eai Branch River located in about $22 \mathrm{~km}$ from mouth. Wave celerity in the river downstream area was calculated equal to $23.9 \mathrm{~km} / \mathrm{h}$ and decreasing due to the reduction of water depth. If we assumed the average water depth at the Old Kitakami entrance is about $5.5 \mathrm{~m}$, then the calculated celerity is quite agreement with the result from the shallow water equation which is equal to $26.4 \mathrm{~km} / \mathrm{h}$.
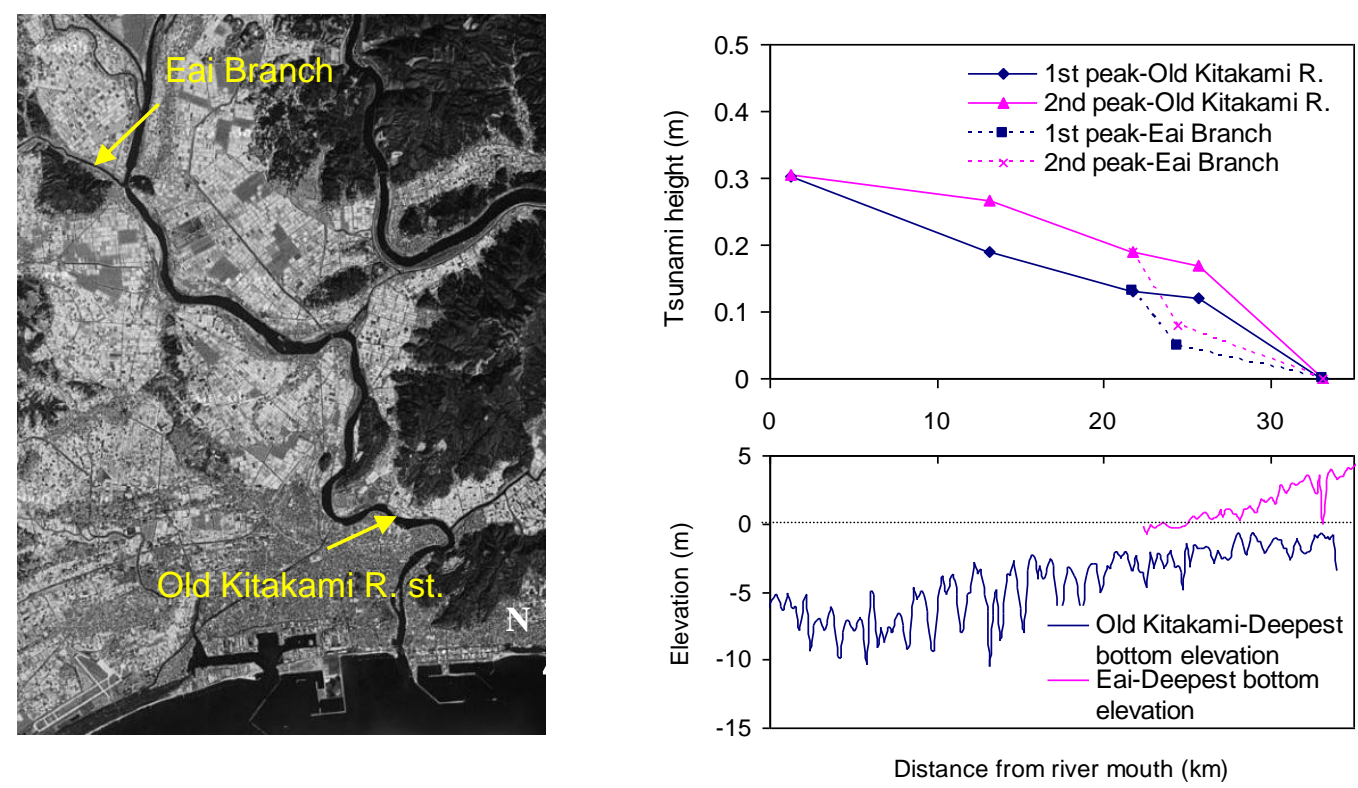

Figure 6. Old Kitakami River morphology and the variation of 1st and 2nd 2010 tsunami peaks along river

\section{The 2011 Tohoku Tsunami Waves Impacts}

The 2011 tsunami waves impacted on most of areas in Japan facing the Pacific Ocean, and Tohoku district were the most impacted areas by the tsunami waves. According to the measurement data from Joint Survey Group, tsunami inundation height was up to $19.5 \mathrm{~m}$ based on T.P. datum in the Sendai Plain in Miyagi Prefecture, and further propagated inland to $5 \mathrm{~km}$ (Mori et al., 2011). Coastal protection structures were destroyed partially or completely in this area. Along the sandy coast, there are many places where serious erosion and breaching of the barriers or sand dunes were found. Especially the sand spits at the mouth of river were completely eroded. Fig. 7 shows the aerial photograph of the Kitakami River area before and after the tsunami event in March 2011 as an example. The Kitakami River is located on the Yokosuka Coast in Miyagi Prefecture (Fig. 1). This 2km-long sandy coast is bounded by the Kitakami River in the north and the Nagatsura Inlet in the south. The river and coastal morphology was completely destroyed by extreme tsunami wave energy. Even up to now the morphology in this area is not recovered yet due to the lack of sediment supply.

The impact of the Tohoku earthquake and tsunami in 2011 is much bigger than the tsunami happened in Chile 2010. With wave height of about 10 meters while in the coastal area plus the subsidence caused by earthquakes makes the most of the coastal areas and estuaries are inundated. Therefore, the classification of river mouth morphology, Type 1 and Type 2 Rivers, may not apply for 
this serious tsunami case. Measuring water stations near the estuary were destroyed partially or completely.

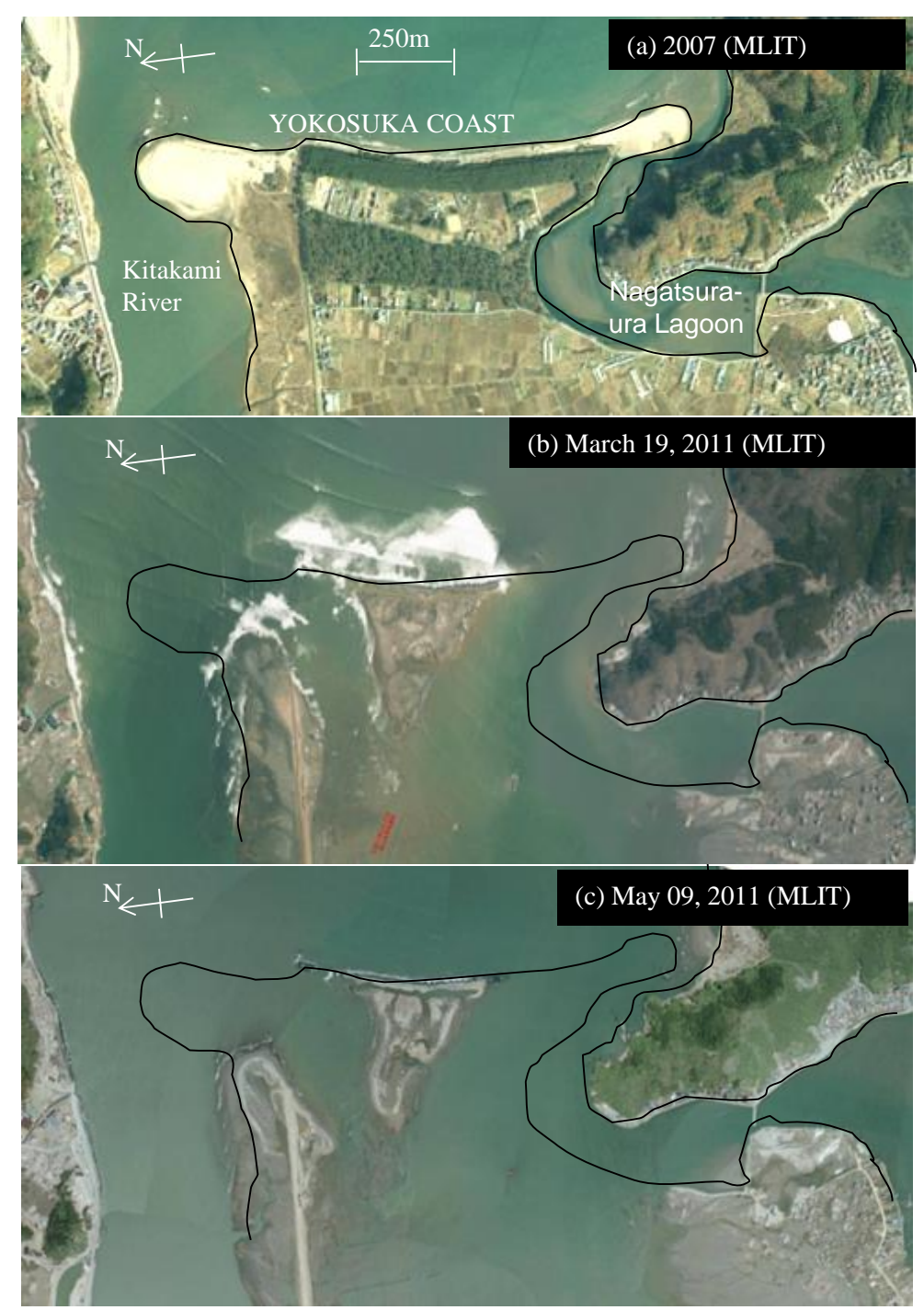

Figure 7. Aerial photographs of the Kitakami River morphology changes caused by the 2011 Tohoku Tsunami

Figure 8 is measured water level data from survived stations along the Kitakami River and Old Kitakami River. The largest tsunami wave height at the Kitakami River was measured about $8 \mathrm{~m}$ at the Tsukihama station. The impact of the tsunami was spread to the Oizumi station which is located about $50 \mathrm{~km}$ from the river mouth. The some water level stations at the Old Kitakami River mouth were destroyed, the nearest available data station is from the Wabuchi station which located in $22 \mathrm{~km}$ from the entrance. Tsunami waves also affected to upstream the EAI tributaries.

Figure 9 is the measured water levels data at stations along the Naruse and Yoshida Rivers. These two rivers share the same river entrance. The maximum of observed tsunami height are $6.63 \mathrm{~m}$ and $6.31 \mathrm{~m}$ at the Naruse River and Yoshida River, respectively. The tsunami was then further propagated to $36 \mathrm{~km}$ upstream area. 


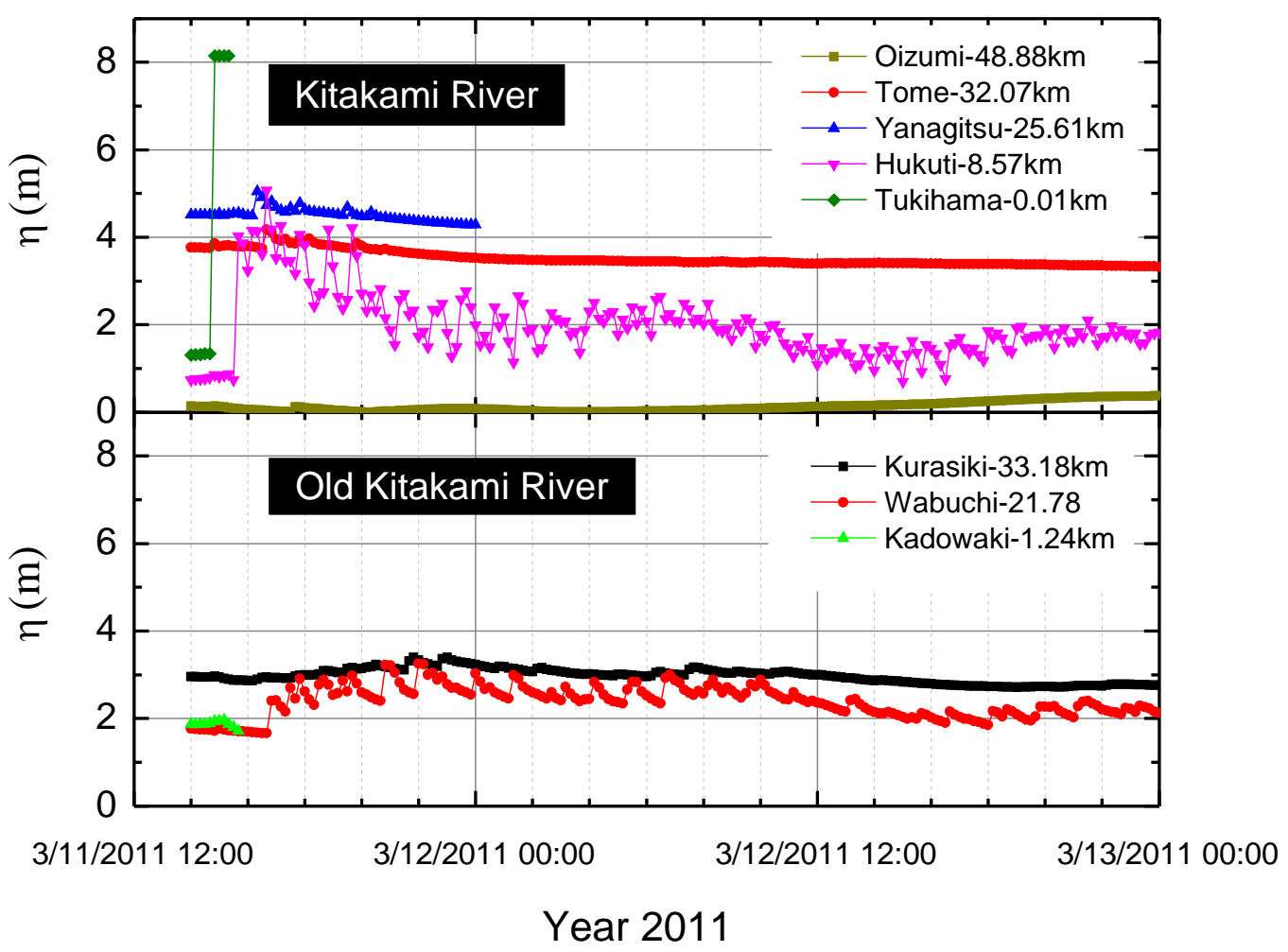

Figure 8. The 2011 Tsunami variations along the Kitakami and Old Kitakami Rivers

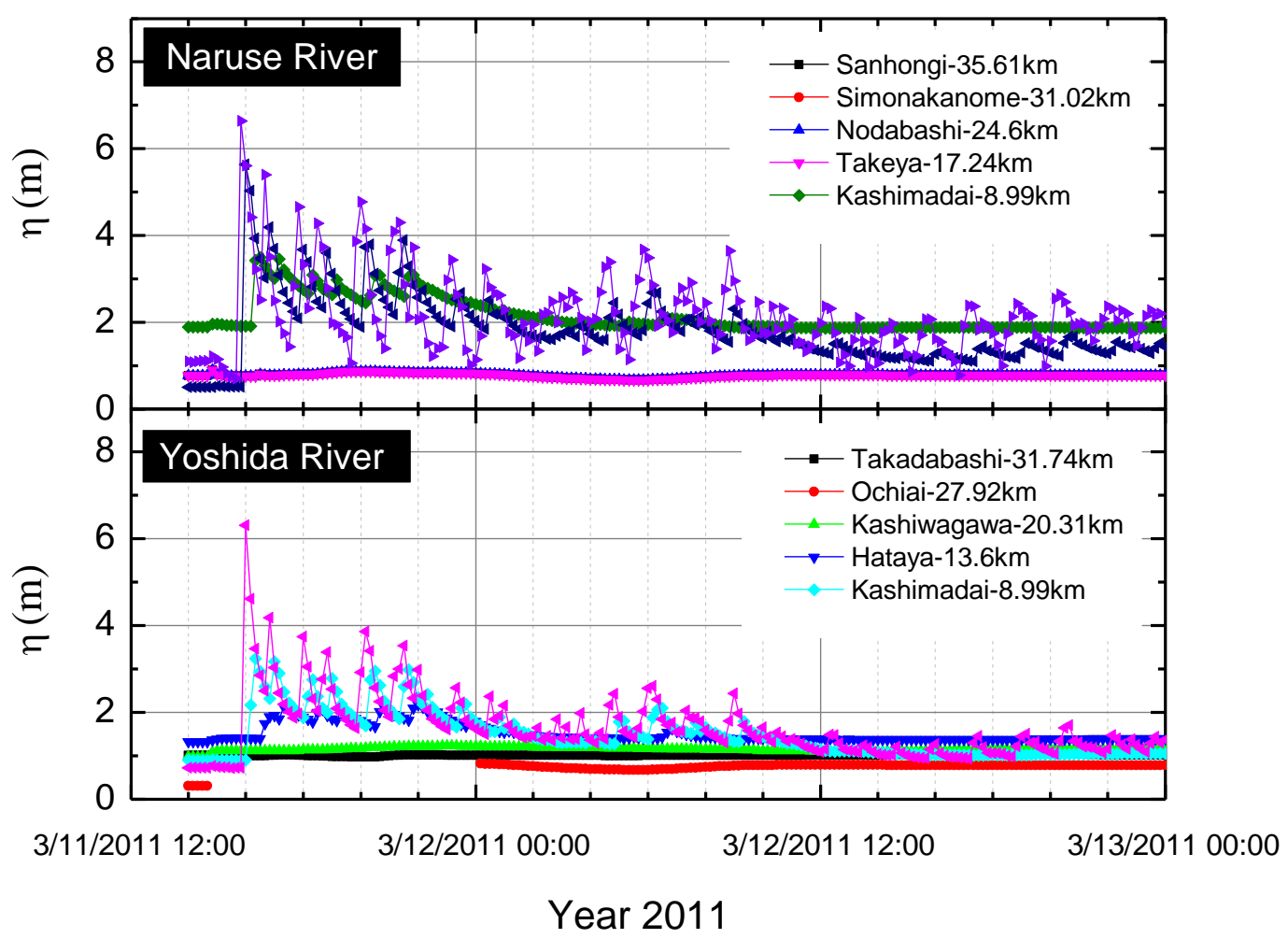

Figure 9. The 2011 Tsunami variations along the Nasure and Yoshida Rivers 
Under the impact of tsunami waves, the river bed was also severely eroded as observed in the Natori River (see Fig. 10). According to the measurement of the water depth at the Natori river entrance, the maximum water depth doubled from the original depth as shown in Fig. 10 at the crosssection at $-1.0 \mathrm{~km}$ from the Teizan Canal. Similar behavior of river bottom erosion was also observed in further river upstream at the cross-sections at $-0.8 \mathrm{~km},-0.2 \mathrm{~km}$ and $0.0 \mathrm{~km}$. The increase of the water depth in the river mouth may cause many problems such as erosion or deposition along the river channel due to waves because waves may easily propagate further upstream of the river.
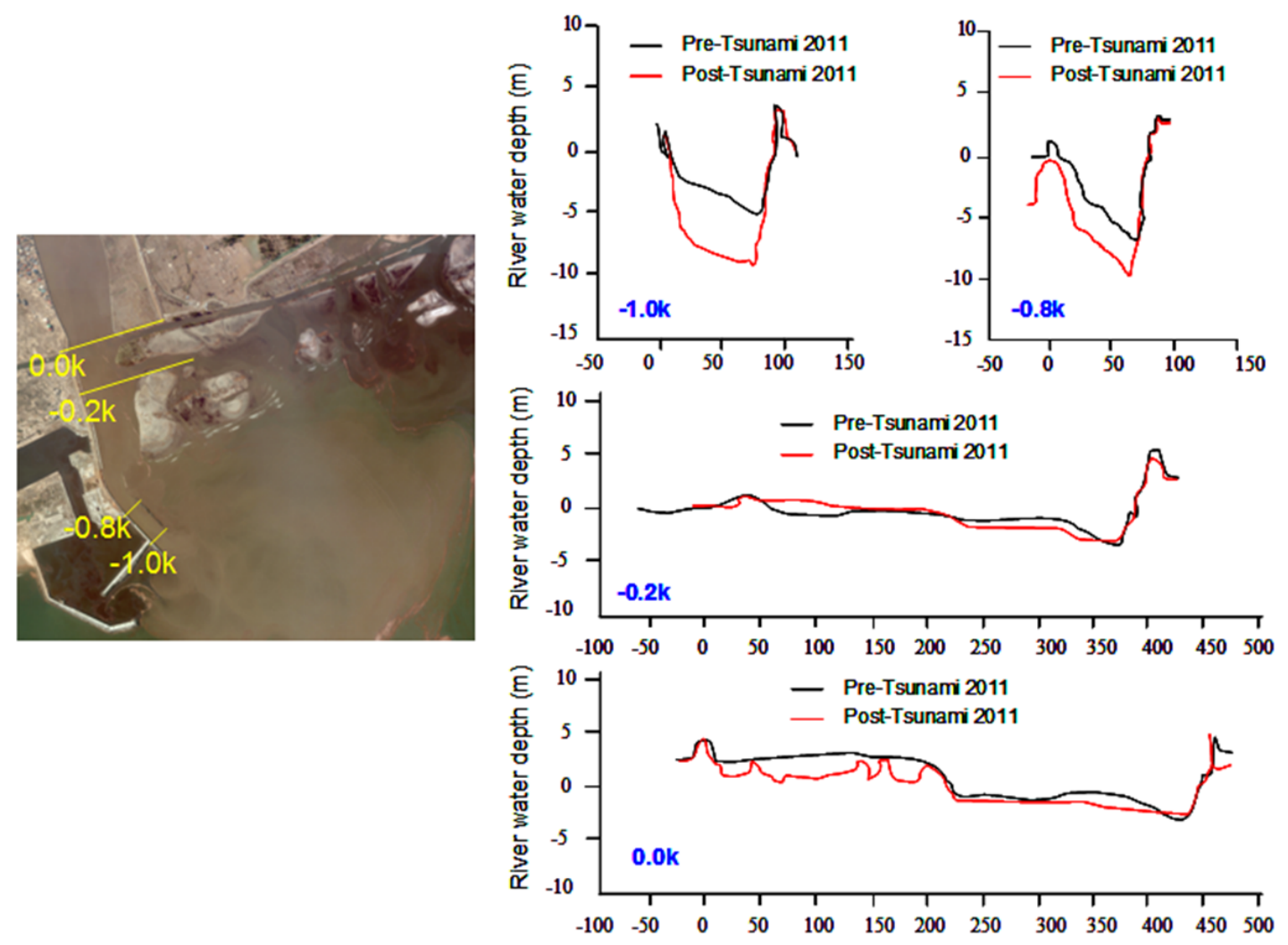

Figure 10. Deeping of river bed elevation at the Natori River

Figure 11 is a summary comparison of the maximum tsunami height that measured at nearest river estuary for all the researched rivers over two earthquake tsunamis in 2010 and 2011. Overall, the impacts of the tsunami waves on the river mouth morphology, Type 1, is larger compared to the Type 2 Rivers. Tsunami height measurements are generally higher and spread farther upstream of the river. This is because the river channel structures at mouth make the tsunami waves were easy to pass through the estuary area; whereas the tsunami energy will be dissipated by the bottom friction or constriction of river entrance before spreading into the river upstream area. Therefore, river managers must pay more attention to the impact of the tsunami to the differences of river morphology.

Due to the magnitude of the tsunami in 2011 was so terrible that most of the river were submerged under water and were partially or completely destroyed measuring stations along the estuary. The analyzed tsunami data are based on most nearby river estuary as shown in Fig. 11. First measured maximum tsunami runup height during the 2011 Tohoku Tsunamis is much larger than in 2010. 


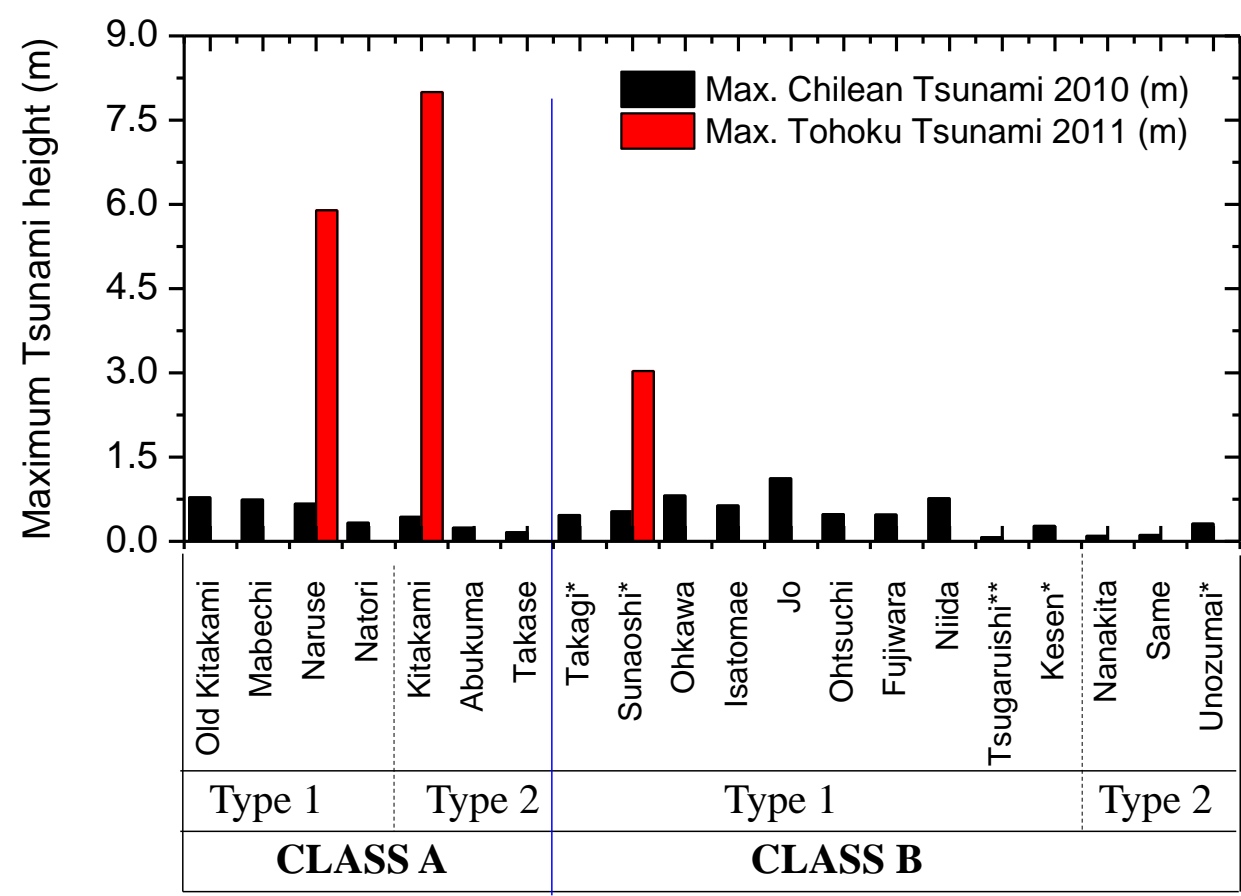

Figure 11. Comparison of maximum observed tsunami runup height at nearest river mouth stations for the 2010 Chilean Tsunami and 2011 Tohoku Tsunami

\section{CONCLUSIONS}

A comprehensive study on the impacts of the 2010 Chilean and 2011 Tohoku Tsunami waves to various river geometries, in the Tohoku Region of Japan was carried out. The tsunami can propagate up to several ten kilometres upstream in a deep river and less distance in a shallow river. The results of this study indicate that tsunami has more impacts to the Type 1 Rivers in terms of wave height and upstream most distance propagation. The maximum observed tsunami travel distance is about $50 \mathrm{~km}$ and measured tsunami travel time inside the river is almost similar to the tsunami travel time calculated by using the long wave theory.

The deepening of river water depth at the entrance due to tsunami impacts can cause a lot of problems such as floodplain erosion or deposition in the river due to waves further penetrating inside of river mouth.

This empirical study is helpful for river authority, river management and engineers to find out the best solution in controlling the river environment and structure design in the river and to warn river upststream people about the tsunami influances.

\section{ACKNOWLEDGMENTS}

The authors wish to express grateful thanks to the Kitakami River Lower Reach Office, the Ministry of Land, Infrastructure and Transport as well as Sendai Office of River and National Highway, Ministry of Land Infrastructure and Transport for providing us aerial photographs and other data sets. Their appreciation should be extended to the Miyagi Prefectural Archives for their permission to use the old map in the present paper. This research could not be conducted without the financial supports from the Grant-in-Aid for Scientific Research from JSPS (No. 21-360230, No. 22360193), Grant-in-Aid for Scientific Research from the River Environmental Fund (REF) in charge of the Foundation of River and Watershed Environmental Management (FOREM), and the Collaborative Research Fund, Disaster Prevention Research Institute, Kyoto University, as well as Assistance for Technological Development, Tohoku Construction Association. The authors would like to gratefully appreciate their supports. 


\section{REFERENCES}

Abe K., 1986: Tsunami propagation in rivers of the Japanese Islands, Continental Shelf Research, Vol. 5, No.6, pp. 655-677.

Mori, N., Takahashi, T., Yasuda, T. \& Yanagisawa, H. , 2011. "Survey of 2011 Tohoku earthquake tsunami inundation and run-up," Geophysical Research Letters 38 doi:10.1029/2011GL049210.

Roh M., Tinh N. X., Tanaka H., 2011: Effect of river mouth morphology on tsunami propagation ascending rivers, Journal of JSCE, Ser.A2 (Applied Mechanics), 14, p.607-614.

Sato H., T. Shimamoto, A. Tsutsumi and E. Kawamoto, 1995: Onshore tsunami deposits caused by the 1993 Southwest Hokkaido and 1983 Japan Sea earthquakes, Pure and Applied Geophysics, Vol.144, No.3-4, pp. 693-717.

Tanaka H. and Tinh N. X., Dao N. X., 2011: Field measurement and numerical studies on the tsunami propagation into upstream of rivers, Proceedings of 34th IAHR Congress, Brisbane, Australia. (CD-ROM)

Tanaka H., K. Ishino, B. Nawarathna, H. Nakagawa, S. Yano, H. Yasuda, Y. Watanabe and K. Hasegawa, 2008: Field investigation of disasters in Sri Lankan Rivers caused by the 2004 Indian Ocean Tsunami. Journal of Hydroscience and Hydraulic Engineering, Vol.26, No.1, pp. 91-112.

Tanaka H., Tinh N.X., Umeda M., Hirao R., Pradjoko E., Mano A., Udo K., 2012: "Coastal and estuarine morphology changes induced by the 2011 Great East Japan Earthquake Tsunami," Coastal Engineering Journal, 54 (2012) http://dx.doi.org/10.1142/S0578563412500106 (25 pp)

Tinh N. X., and Tanaka H., 2010: The influence of Chilean Tsunami wave in 2010 on rivers in the Tohoku District, Japan, Proceedings of International Sessions of Coastal Engineering Conference, JSCE, pp. 54-60.

Tsuji Y., T. Yanuma, I. Murata, and C. Fujiwara, 1991: Tsunami ascending in rivers as an undular bore, Natural Hazards, Vol.4, pp.257-266.

Yasuda H., 2010: A one-dimensional study on propagation of tsunami wave in river channels, Journal of Hydraulic Engineering, ASCE, Vol.136, No.2, pp.93-105. 